\title{
Apical and periapical repair of dogs' teeth with periapical lesions after endodontic treatment with different root canal sealers
}

\section{Reparação apical e periapical de dentes de cães com lesão periapical crônica após tratamento endodôntico utilizando diferentes materiais obturadores}

\author{
Mário Roberto Leonardo* \\ Antônio Alberto Medeiros Salgado** \\ Léa Assed Bezerra da Silva*** \\ Mário Tanomaru Filho****
}

\begin{abstract}
The aim of this study was to evaluate the apical and periapical repair after root canal treatment of dogs teeth with pulp necrosis and chronic periapical lesion using different root canal sealers. After periapical lesion induction, forty-four root canals of 3 dogs were submitted to biomechanical preparation using $5.25 \%$ sodium hypochlorite as an irrigating solution. A calcium hydroxide dressing (Calen PMCC) was applied for 15 days and the root canals were filled using the lateral condensation technique with gutta-percha points and Sealapex, AH Plus or Sealer Plus for sealing. After 180 days, the animals were sacrificed by anesthetic overdose and the obtained histological sections were stained with hematoxylin-eosin for optical microscopic analysis of the apical and periapical repair. The groups filled with Sealapex and AH Plus had better histological repair $(\mathrm{p}<0.05)$ than the group filled with Sealer Plus, that had unsatisfactory results.
\end{abstract}

DESCRIPTORS: Dental cements; Root canal obturation; Injuries; Periapical abscess; Biocompatible materials.

\begin{abstract}
RESUMO: O objetivo do presente estudo foi avaliar a reparação apical e periapical pós-tratamento endodôntico de dentes de cães com necrose pulpar e reação periapical crônica, em que se utilizaram diferentes materiais obturadores. Foram utilizados 44 canais radiculares, nos quais, após indução das lesões periapicais, foi efetuado o preparo biomecânico empregando-se como solução irrigadora uma solução de hipoclorito de sódio a 5,25\%. Após curativo de demora com pasta à base de hidróxido de cálcio (Calen PMCC), mantida no canal radicular durante 15 dias, os canais radiculares foram obturados pela técnica clássica complementada pela condensação lateral ativa, empregando-se os cimentos Sealapex, AH Plus ou Sealer Plus. Decorrido o período de 180 dias, os animais foram mortos e as peças submetidas ao processamento laboratorial. Os cortes histológicos obtidos foram corados com hematoxilina-eosina. A análise histopatológica demonstrou que nos canais radiculares obturados com os cimentos Sealapex e AH Plus ocorreu melhor reparação $(p<0,05)$ do que nos canais obturados com o Sealer Plus, o qual mostrou resultados insatisfatórios.
\end{abstract}

DESCRITORES: Cimentos dentários; Obturação do canal radicular; Lesões; Abscesso periapical; Materiais biocompativeis.

\section{INTRODUCTION}

An intracanal dressing has been indicated for the treatment of root canals with necrotic pulp and chronic periapical lesions in order to eliminate microorganisms of the root canal system that were not removed by biomechanical preparation ${ }^{1,4,8}$. Calcium hydroxide has been recommended as the intracanal dressing of choice $e^{4,5,7,14}$ due to its antimicrobial action and its capacity to inactivate the effects of Gram-negative bacteria endotoxin $(\text { LPS })^{10,11,12}$ present on cell walls.
A hermetic seal is also an important factor for

the success of apical and periapical repair in teeth with necrotic pulp and chronic periapical lesions. For this, the sealer must not only have satisfactory physicochemical properties, but must also have biological properties that allow or induce apical repair and mineralized tissue deposition. Among the sealers studied, Sealapex (Kerr Corp., Romulus, USA) has presented excellent biocompatibility ${ }^{2,15}$. Even though it is relatively soluble after application, this does not affect its sealing property ${ }^{13}$. In

\footnotetext{
${ }^{*}$ Chairman, Discipline of Endodontics; ${ }^{* * * * A d j u n c t ~ P r o f e s s o r, ~ D i s c i p l i n e ~ o f ~ E n d o d o n t i c s ~-~ S c h o o l ~ o f ~ D e n t i s t r y ~ o f ~ A r a r a q u a r a, ~ S a ̃ o ~}$ Paulo State University.

**Professor, Caruaru School of Dentistry.

${ }^{* * *}$ Chairperson, Pediatric Dentistry, School of Dentistry of Ribeirão Preto, University of São Paulo.
} 
Leonardo MR, Salgado AAM, Silva LAB da, Tanomaru Filho M. Apical and periapical repair of dogs' teeth with periapical lesions after endodontic treatment with different root canal sealers. Pesqui Odontol Bras 2003;17(1):69-74.

fact, this relative solubility allows the ionic dissociation of calcium hydroxide from this sealer, contributing to the induction of apical minerali zation $^{2,16}$ and antibacterial action ${ }^{8}$.

The resin-based epoxy sealer AH Plus (Dentsply De Trey GmbH, Konstanz, Germany) has shown satisfactory biological results after root canal filling in teeth with vital pulp ${ }^{6}$. Sealer Plus, also a resin-based sealer, manufactured by Dentsply (Petrópolis, RJ, Brazil) is in an experimental phase. This sealer consists of two pastes and contains calcium oxide.

Thus, the objective of this study was the comparative evaluation of those 3 endodontic sealers in the treatment of dog root canals with chronic periapical lesions.

\section{MATERIAL AND METHODS}

The second, third and fourth mandibular premolars and the second and third maxillary premolars of three mongrel dogs (aged 12 to 18 months; both sexes), totaling 44 roots, were selected for treatment and divided into 3 groups.

The root canals were initially explored with no. 20 K-files (Dentsply Maillefer, Ballaigues, Switzerland) and the pulp was removed with no. 30/40 Hedströen files (Dentsply Maillefer, Ballaigues, Switzerland), depending on the root canal diameter. The root canals remained exposed to the oral cavity for 7 days, in order to allow bacterial contamination.

After this period, the pulp chamber was cleaned and dried, cotton pellets were placed in the pulp chamber and the coronal opening was sealed with zinc oxide-eugenol cement (Pulpo-San, S. S. White, Rio de Janeiro, RJ, Brazil). After 30 days, radiographs were taken every 15 days, according to Leonardo et al. ${ }^{9}$ (1993), until radiolucent images

TABLE 1 - Sealapex (approximate composition, according to Kerr Corporation).

\begin{tabular}{l|c|l|r}
\hline \hline \multicolumn{2}{c|}{ Base } & \multicolumn{2}{c}{ Catalyst } \\
\hline Calcium oxide & $54.0 \%$ & Barium sulfate & $40.0 \%$ \\
\hline $\begin{array}{l}\text { Ethyl toluene } \\
\text { sulfonamide }\end{array}$ & $32.0 \%$ & $\begin{array}{l}\text { Poly(methylene- } \\
\text { methylsalicylate) resin }\end{array}$ & $30.0 \%$ \\
\hline Zinc oxide & $14.0 \%$ & Isobutyl salicylate & $18.0 \%$ \\
\hline Water & $0.01 \%$ & Sub-micron silica & $7.0 \%$ \\
\hline & & Titanium dioxide & $4.0 \%$ \\
\cline { 2 - 4 } & Pigment & $1.0 \%$ \\
\hline \hline
\end{tabular}

suggesting chronic periapical reaction were observed, which normally occurs after 45-60 days.

Under new anesthesia and rubber dam placement, crown-down neutralization of the root canal septic/toxic content was performed using K-files and $3.6 \mathrm{ml}$ of $5.25 \%$ sodium hypochlorite after each instrument. The teeth were instrumented $2 \mathrm{~mm}$ from the radiographic apex. Enlargement of the apical foramen was performed up to a no. 30 file to the total tooth length. In this same session, biomechanical preparation was performed with K-files following classic instrumentation according to $\mathrm{Leal}^{3}$ (1998), up to a no. 70 instrument. A no. 30 file was reinserted to the total tooth length to remove possible dentin chips taken to the apex during instrumentation. The root canals were dried and a $17 \%$ EDTA solution was used with continuous agitation with a $\mathrm{K}$-file for 3 minutes and were again irrigated and dried with sterile absorbent paper points. A calcium hydroxide camphorated $\rho$-monochlorophenical intracanal dressing (Calen PMCC, S. S. White Artigos Dentários Ltda., Rio de Janeiro, RJ, Brazil) was used for 15 days. The coronal openings were sealed with quick-setting zinc oxide-eugenol cement.

After 15 days, under anesthesia and rubber dam placement, the intracanal dressing was removed with $0.5 \%$ sodium hypochlorite and a no. 70 file, and the root canals were dried with sterile absorbent paper points. A no. 30 file was again applied to the total tooth length and the root canals were irrigated with $17 \%$ EDTA for 3 minutes. The master gutta-percha cones (Tanari Ind., Manaus, AM, Brazil) were selected and the root canals were sealed with Sealapex (Table 1), AH Plus (Table 2) or Sealer Plus (Table 3) following the classical technique complemented by active lateral condensation. The sealers were manipulated in equal parts (base and catalyst) until a homogenous color with clinical consistency was obtained.

Root canal sealing was radiographically analyzed and the coronal openings were sealed with

TABLE 2 - AH Plus (approximate composition, according to Dentsply De Trey, Konstanz, Germany).

\begin{tabular}{c|c}
\hline \hline Paste A & Paste B \\
\hline Epoxy resins & Amines \\
\hline Calcium tungstate & Calcium tungstate \\
\hline Zirconium oxide & Zirconium oxide \\
\hline Silica & Silica \\
\hline Iron oxide pigments & Silicone oil \\
\hline \hline
\end{tabular}


Leonardo MR, Salgado AAM, Silva LAB da, Tanomaru Filho M. Apical and periapical repair of dogs' teeth with periapical lesions after endodontic treatment with different root canal sealers. Pesqui Odontol Bras 2003;17(1):69-74.

silver amalgam (Velvalloy, S. S. White Artigos Dentários, Rio de Janeiro, RJ, Brazil) condensed over a glass ionomer base (Vitremer, 3M do Brasil, Campinas, SP, Brazil).

After 180 days, the animals were sacrificed by anesthetic overdose, the roots were fixed for histological analysis in sodium cacodylate and demineralized with EDTA. The obtained blocks were cut serially in $6-\mu \mathrm{m}$-thick sections and stained with hematoxylin-eosin.

The histopathological analysis results were evaluated by the Mann-Whitney test.

\section{RESULTS \\ Group I: Sealapex}

The 10 roots sealed with Sealapex cement after 15 days of Calen PMCC intracanal dressing showed the following histopathological characteristics: in the apical cementum, the cementum lacunae were filled by normal connective tissue and the space frequently decreased by mineralized tissue formation. Newly formed mineralized tissue on the apical foramen walls was observed in direct contact with the sealing material, totally sealing the foramen in 4 roots. Four of the 6 remaining roots had extensive mineralized newly formed tissue that partially sealed the apical foramen with connective tissue invaginating the periapex. This interstitial tissue was normal and contained collagen fibers, fibroblasts, blood vessels and sealer particles (Figures 1 and 2). The apical cementum surface was regular due to newly formed cementum in previously reabsorbed areas. The alveolar bone showed regular trabeculae with osteocytes within the bone and osteoblasts at its surface. The periapical region was slightly enlarged in 5 roots, moderately enlarged in 4 roots and severely enlarged in 1 root.

TABLE 3 - Sealer Plus (approximate composition, according to Dentsply).

\begin{tabular}{c|c}
\hline \hline Base & Catalyst \\
\hline Calcium oxide & Calcium oxide \\
\hline Bismuth trioxide & Bismuth trioxide \\
\hline Calcium stearate & Titanium dioxide \\
\hline Epoxy resins & Silicone oil \\
\hline Oxide & \\
\hline \hline
\end{tabular}

\section{Group II: AH Plus}

From the 18 root canals that received the Calen PMCC intracanal dressing for 15 days and were sealed with AH Plus, 4 had total apical sealing with newly formed mineralized tissue and 12 had partial sealing (Figure 3). No sealing occurred in 2 roots. The apical cementum surface was regular with newly formed cementum in previously reabsorbed areas, with few cementoblasts and collagen fibers. The cementum lacunae in the apical region were frequently empty or contained normal connective tissue in a few roots. The periapical region was slightly enlarged in 11 specimens, moderately enlarged in 5 and severely enlarged in 2 roots. In this region, the inflammatory infiltrate was mild and diffuse in 14 roots, composed of phagocytic mononuclear cells. Thin alveolar bone formation was found surrounding all of the apices that were frequently denuded or with reduced osteoclasts on their surface. In the roots in which the material

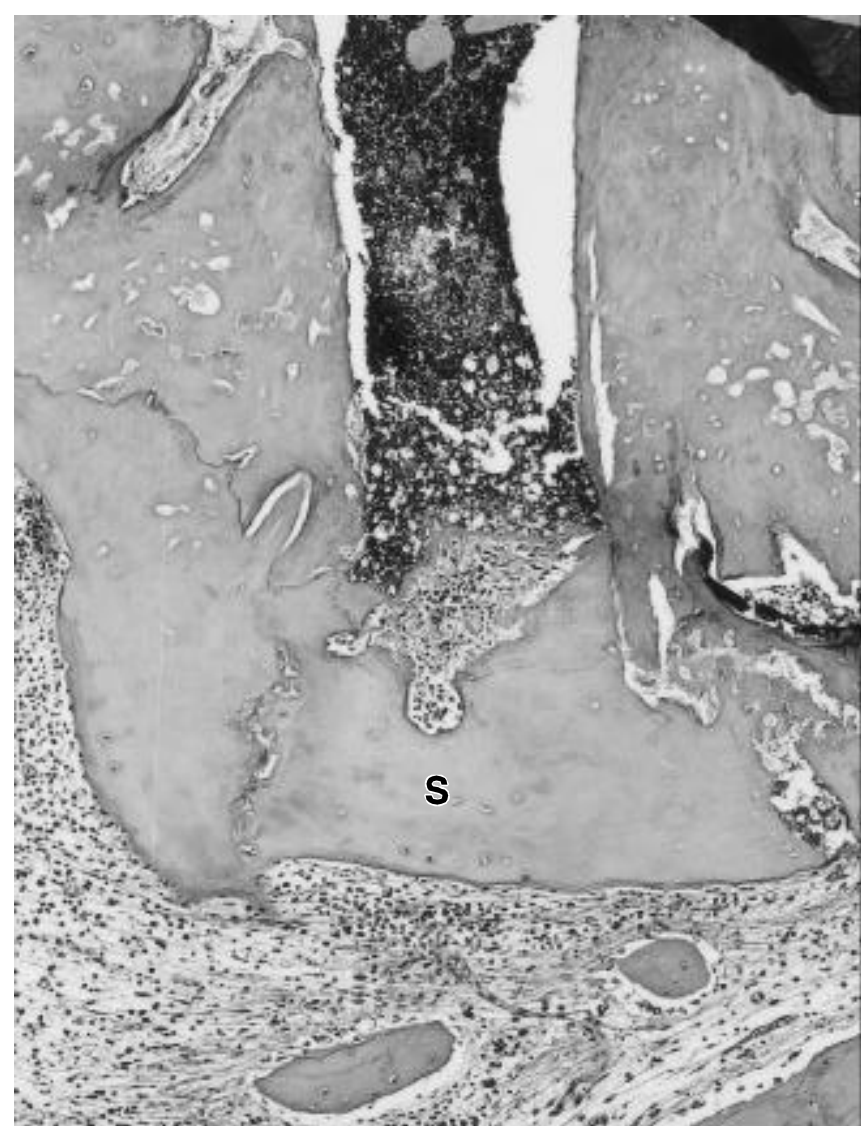

FIGURE 1 - Group I (Sealapex) - biological sealing of the apex with mineralized tissue deposition (S). Mild and diffuse infiltration of inflammatory cells in the apical periodontal ligament close to the alveolar bone $(\mathrm{H}$. E. Olympus - $40 \mathrm{X}$ ). 


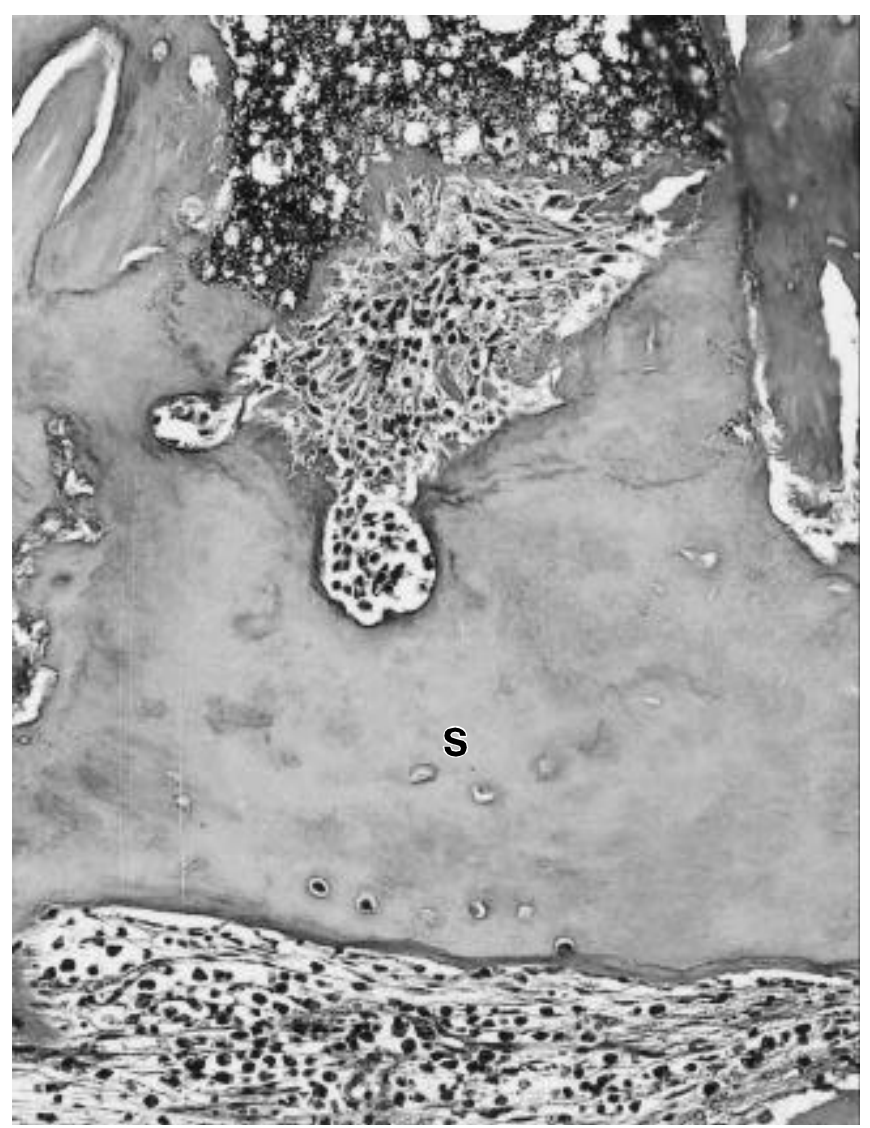

FIGURE 2 - Group I (Sealapex) - greater magnification of Figure 1 shows deposition of mineralized tissue (S) (H. E. - Olympus - $100 \mathrm{X}$ ).

was overfilled to the periapical region, a fibrous capsule surrounded it, with no inflammatory cells.

\section{Group III: Sealer Plus}

In the 16 root canals from this group, which had a Calen PMCC intracanal dressing for 15 days and were sealed with Sealer Plus, total apical closure was observed in only 2 roots, partial sealing, in 8 roots and lack of sealing, in 6 specimens. Among these 6 specimens, 4 were overfilled. In the apical cementum, the lacunae were frequently empty and enlarged. The cementum surface near the apical foramen was repaired by newly formed tissue and demarked by basophilic lines. Some areas of cementum resorption persisted laterally to the apical foramen, especially in the regions near secondary canals, with a moderate presence of adjacent inflammatory cells. The periodontal ligament was moderately thicker in 7 roots and slightly thicker in 9 . In this region, there was incomplete repair in 10 specimens, represented by a

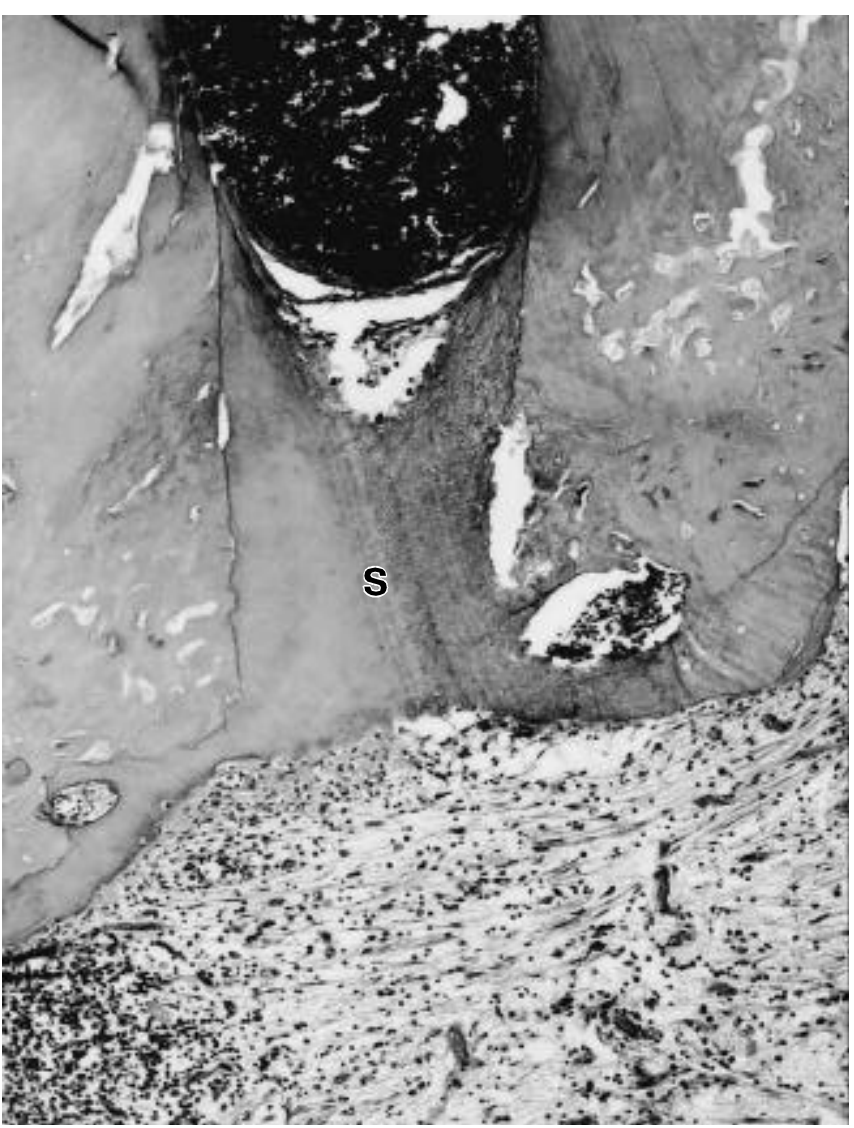

FIGURE 3 - Group II (AH Plus) - complete biological sealing (S) of the root apex with deposition of mineralized tissue. Moderate presence of inflammatory cells on the apical periodontal ligament (H. E. - Olympus - $40 \mathrm{X}$ ).

reduced quantity of collagen fibers and fibroblasts. The inflammatory infiltrate was predominantly mononuclear and spread diffusely around the apex, with a considerable number of congested blood vessels (Figures 4 and 5). The alveolar bone was denuded or had occasional osteoclasts on its surface. In cases of overfilling, there were inflammatory cells with giant cells in direct contact with the extruded sealer.

\section{DISCUSSION}

The ideal root canal sealer should have excellent physicochemical properties and biological compatibility, because a sealer remains in direct contact with apical and periapical tissues.

The results of the present study show that Sealapex and AH Plus allowed greater deposition of mineralized tissue than did Sealer Plus. The biocompatibility of Sealapex has already been amply evaluated in teeth with vital pulp by Holland, Souza $^{2}$ (1985), Tagger et al. ${ }^{16}$ (1988), and by 


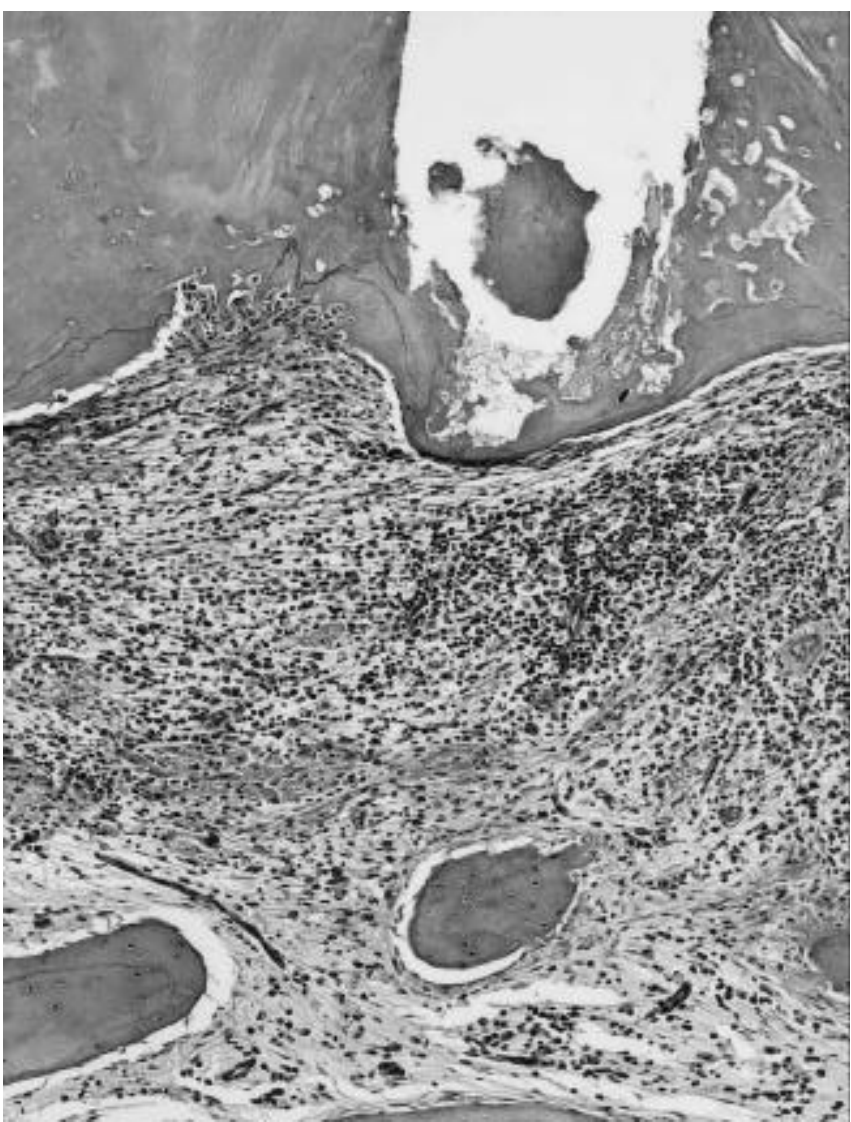

FIGURE 4 - Group III (Sealer Plus) - partial biological sealing of the apex with little deposition of mineralized tissue. Moderate and diffuse inflammatory infiltrate on the apical periodontal ligament (H. E. - Olympus - $40 \mathrm{X})$.

Tanomaru Filho et al. ${ }^{17}$ (1998) in dog's teeth with periapical lesions. Because AH Plus is a new sealer, there are few biocompatibility studies about it; however, current research shows that this material is biocompatible with apical and periapical tissues. Mineralized tissue formation and lack of inflammation have also been reported $^{6}$, presenting results similar to those of the present study.

On the other hand, Sealer Plus has not shown satisfactory biological results. Its tissue response was similar to that of AH 26 and Sealer 26, which have similar chemical compositions.

In the cases in which the sealer was restricted to the interior of the root canal, only root canals filled with Sealapex had deposition of mineralized tissue forming a partial or total seal in $100 \%$ of the cases. The same was not observed with AH Plus nor with Sealer Plus.

In cases of overfilling, the inflammatory response was similar in root canals filled with $\mathrm{AH}$ Plus and Sealapex ( $p>0.05)$, and was lesser than that observed with Sealer Plus $(p<0.05)$.

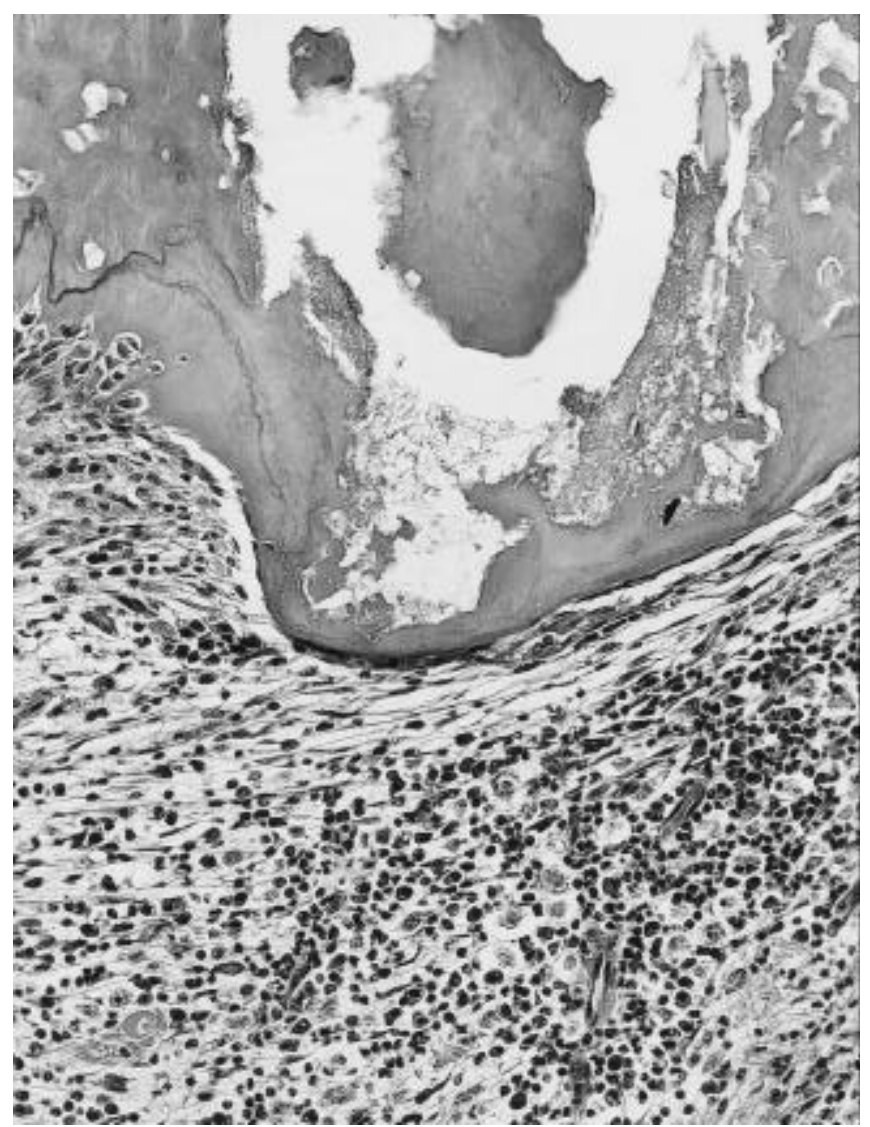

FIGURE 5 - Group III (Sealer Plus) - higher magnification of Figure 4 shows moderate and diffuse inflammatory infiltrate (H. E. - Olympus - $100 \mathrm{X})$.

In the present study, frequent areas of repaired cementum absorption were found, as well as the presence of cementoblasts and collagen fibers with Sealapex. Only 6 roots out of the 16 root canals filled with Sealer Plus showed repaired cementum.

The insolubility of Sealer Plus, associated with its irritating action, has probably produced the permanent activation of cellular inflammation, leading to the unsatisfactory effects observed in the apical and periapical tissues.

\section{CONCLUSIONS}

Based on the results obtained in the histopathological analysis of apical and periapical tissues, we conclude that:

- The root canal sealers Sealapex and AH Plus showed satisfactory tissue responses leading to the repair of the apical and periapical regions.

- Sealer Plus showed unsatisfactory histopathological results and considerable tissue irritant action. 
Leonardo MR, Salgado AAM, Silva LAB da, Tanomaru Filho M. Apical and periapical repair of dogs' teeth with periapical lesions after endodontic treatment with different root canal sealers. Pesqui Odontol Bras 2003;17(1):69-74.

\section{REFERENCES}

1. Chong BS, Pitt Ford TR. The role of intracanal medication in root canal treatment. Int Endod J 1992;25:97-106.

2. Holland R, Souza V. Ability of a new calcium hydroxide root canal filling material to induce hard tissue formation. J Endod 1985;11:535-43.

3. Leal JM. Preparo biomecânico dos canais radiculares meios mecânicos. In: Leonardo MR, Leal JM. Endodontia: tratamento de canais radiculares. $3^{\mathrm{a}}$ ed. São Paulo: Panamericana; 1998. p.367-88.

4. Leonardo MR, Silva LAB. Medicação tópica entre sessões, "curativo de demora" em biopulpectomia e necropulpectomia. In: Leonardo MR, Leal JM. Endodontia: tratamento de canais radiculares. São Paulo: Panamericana; 1998. p.491-534.

5. Leonardo MR, Almeida WA, Silva LAB, Utrilla LS. Histopathological observations of periapical repair in teeth with radiolucent areas submitted to two different methods of root canal treatment. J Endod 1995;21:137-41.

6. Leonardo MR, Silva LAB, Almeida WA, Utrilla LS. Tissue response to an epoxy resin-based root canal sealer. Endod Dent Traumatol 1999;15:28-32.

7. Leonardo MR, Silva LAB, Tanomaru Filho M, Silva RS. Release of formaldehyde by 4 endodontic sealers. Oral Surg Oral Med Oral Pathol Oral Radiol Endod 1999;88:221-5.

8. Leonardo MR, Silva LAB, Tanomaru Filho M, Bonifácio KC, Ito IY. In vitro evaluation of antimicrobial activity of sealers and pastes used in endodontics. J Endod 2000;26:391-4.
9. Leonardo MR, Silva LAB, Leonardo RT, Utrilla LS, Assed S. Histological evaluation of therapy using a calcium hydroxide dressing for teeth with incompletely formed apices and periapical lesions. J Endod 1993;19:348-52.

10. Safavi KE, Nichols FC. Effect of calcium hydroxide on bacterial lipopolysaccharide. J Endod 1993;19:76-8.

11. Safavi KE, Nichols FC. Alteration of biological properties of bacterial lipopolysaccharide by calcium hydroxide treatment. J Endod 1994;20:127-9.

12. Silva LAB, Nelson-Filho P, Leonardo MR, Rossi MA, Pansani CA. Effect of calcium hydroxide on bacterial endotoxin in vivo. J Endod 2002;28:94-8.

13. Sleder FS, Ludlow MO, Bohacek JR. Long-term sealing ability of a calcium hydroxide sealer. J Endod 1991;17:541-3.

14. Souza V, Bernabé PFE, Holland R, Nery MJ, Mello W, Otoboni Filho JA. Tratamento não-cirúrgico de dentes com lesões periapicais. Rev Bras Odontol 1989;46:39-46.

15. Tagger $M$, Tagger E. Periapical reaction to calcium hydroxide-containing sealers and AH 26 in monkeys. Endod Dent Traumatol 1989;5:139-46.

16. Tagger M, Tagger E, Kfir A. Release of calcium and hydroxyl ions from set endodontic sealers containing calcium hydroxide. J Endod 1988;14:588-91.

17. Tanomaru Filho M, Leonardo MR, Silva LAB, Utrilla LS. Effect of different root canal sealers on periapical repair of teeth with chronic periradicular periodontitis. Int Endod J 1998;31:85-9.

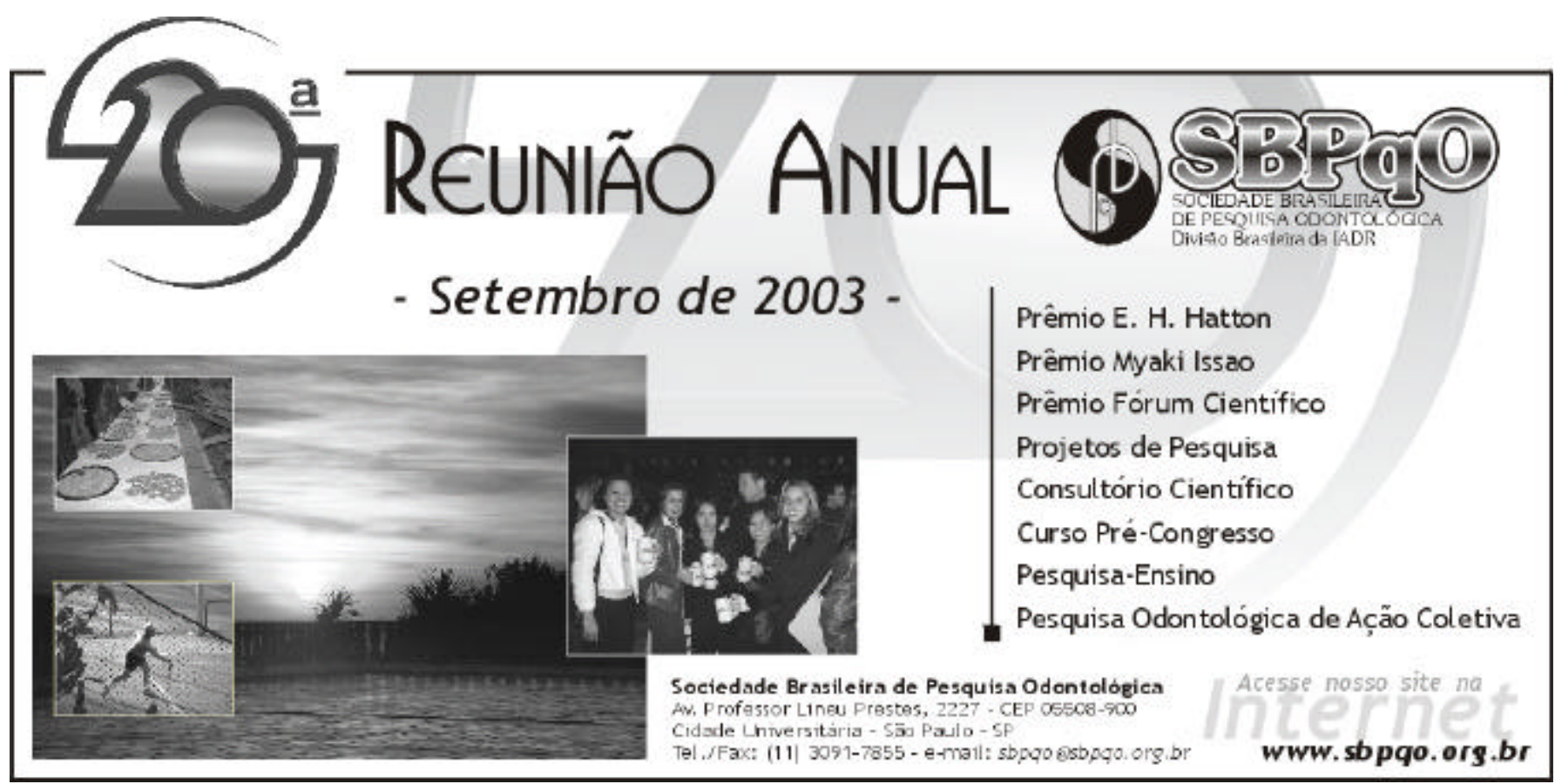

